\title{
Effect of Rosemary (Rosmarinus officinalis L.) Supplementation on Probiotic Yoghurt: Physicochemical Properties, Microbial Content, and Sensory Attributes
}

\author{
Haider I. Ali ${ }^{1}$, Mithun Dey ${ }^{2}$, Azalldeen Kazal Alzubaidi ${ }^{3}{ }^{\circledR}$, Sadiq Jaafir Aziz Alneamah ${ }^{4}$, \\ Ammar B. Altemimi ${ }^{1}$ (D) and Anubhav Pratap-Singh ${ }^{2, *(D)}$ \\ 1 Department of Food Science, College of Agriculture, University of Basrah, Basrah 61004, Iraq; \\ haider.ali@uobasrah.edu.iq (H.I.A.); ammar.ramddan@uobasrah.edu.iq (A.B.A.) \\ 2 Food Nutrition and Health Program, Faculty of Land \& Food Systems, The University of British Columbia, \\ 2205 East Mall, Vancouver, BC V6T 1Z4, Canada; mithun.pharma85@gmail.com \\ 3 College of Agriculture, University of Misan, Al-Amara 62001, Iraq; ez_aldeen@uomisan.edu.iq \\ 4 Food Science Department, Agriculture College, Kufa University, Al-Najaf 54001, Iraq; \\ sadiqj.almusawi@uokufa.edu.iq \\ * Correspondence: anubhav.singh@ubc.ca
}

\section{check for}

updates

Citation: Ali, H.I.; Dey, M.; Alzubaidi, A.K.; Alneamah, S.J.A.; Altemimi, A.B.; Pratap-Singh, A. Effect of Rosemary (Rosmarinus officinalis L.) Supplementation on Probiotic Yoghurt: Physicochemical Properties, Microbial Content, and Sensory Attributes. Foods 2021, 10, 2393. https://doi.org/10.3390/ foods10102393

Academic Editor: Vito Verardo

Received: 30 August 2021

Accepted: 29 September 2021

Published: 9 October 2021

Publisher's Note: MDPI stays neutral with regard to jurisdictional claims in published maps and institutional affiliations.

Copyright: (c) 2021 by the authors. Licensee MDPI, Basel, Switzerland. This article is an open access article distributed under the terms and conditions of the Creative Commons Attribution (CC BY) license (https:/ / creativecommons.org/licenses/by/ $4.0 /)$.
Abstract: Rosemary (Rosmarinus officinalis L.) is a natural aromatic plant that belongs to the family of Lamiaceae. The rosemary plant has been utilized to preserve food due to its ability to prevent oxidation and microbial contamination. This study aimed to investigate the effect of fortifying yoghurt with rosemary extracts and probiotic bacteria (LAB) (Bifidobacterium longum ATCC15707 and two lactic acid bacteria, Streptococcus thermophilus and Lactobacillus delbrueckii subsp. bulgaricus) on its chemical composition, total phenolic compounds, antioxidant capacity, and sensory properties. The study results revealed significant differences in the total solids, protein, and ash content when rosemary concentration increased beyond $2 \%$. However, there were no significant differences among the treatments in acidity and $\mathrm{pH}$ value. The sensory evaluation results indicated that the addition of aqueous extract of rosemary affected the sensory properties of yoghurt (flavour, body and texture, appearance, and overall grade), wherein an increasing concentration of rosemary extract increased score of flavour, body and texture, appearance, and overall grade. On the other hand, rosemary extract did not affect the sensory properties and chemical composition. To sum up, it can be stated that rosemary was used in the preparation of yoghurt with increased health benefits, acceptable sensory attributes, and the production of synbiotic yogurt.

Keywords: antioxidant; total phenolic compound; probiotic; functional food; rosemary; yoghurt

\section{Introduction}

Functional food refers to all kind of foods which deliver important physiological functions and provide nutrients that immensely help in maintaining our body function with additional health advantages [1]. The term 'functional' foods has not found any widely accepted definition, because every country has accepted different ideas to define the terminology of functional foods [2]. Functional foods can be defined "as intact foods that include the different categories of foods, for instance, fortified, enhanced, and enriched foods, which when taken daily as part of the various diets at the effective levels produce usefully advantageous effects on health" [1]. Due to the wide propagation of lifestylerelated diseases such as obesity, cancer, diabetes, and cardiovascular diseases such as elevated blood pressure and increased cholesterol, functional foods have generated great attention today [2]. Arguably, all kinds of food items can be considered functional to some extent as they deliver essential energy and nutrients predominantly required for us to maintain a healthy life. However, foods are scientifically termed 'functional' only when particular nutrients or active ingredients (like beneficial bacteria) scientifically proven 
to enhance human health are fortified, enhanced or enriched in intact food products. Functional foods can comprise the fundamentally nutritional elements in natural products such as vegetables and fruits; or can comprise nutrients not naturally found in those products like fortified food products such as vitamin D-fortified milk and vitamin Cfortified fruit juices; probiotics, prebiotics, whole grains, and fibers [3].

The word 'probiotic' comes from the Greek term "pro" which means "for" and the Greek term "bios," which means "life". Probiotic yoghurt is considered a functional food with a beneficial effect on human health [4]. For example, it can prevent constipation, regarded as one of the most prevalent gastrointestinal problems [5]. The related health advantages include relief of lactose intolerance symptoms, diarrhea treatment, cancer suppression, and reduced blood cholesterol levels. In reality, a product's matrix can affect the behavior of microbes and thus the microbe's survival and effects, and thus deserves close attention [6].

Rosemary oil is used as a food seasoning for food [7]. Rosemary oil has traditionally and largely been used as a medicinal herb with number of properties such as antiinflammatory, analgesic, astringent, antimicrobial, anti-rheumatic, carminative, antifungal, and antioxidant properties [8]. Natural phenolic compounds that have been found in plants and vegetables may decrease the risk of some diseases because of their antioxidant and free-radical inhibition potentials imparted by the benzene ring and the hydroxyl group in their structures [9-11]. These phenolic compounds are the result of secondary metabolism in plants, and are often utilized with the intention of therapeutic activity due to their pharmacological features [8,9]. More than 8000 phenolic structures have been described, including essential activities in the propagation and development of the plants, wherein they have a significant function as protection specialists against pathogens, parasites, and provide enhancements to the color of plants [12].

The Rosmarinus officinalis L. is familiar as rosemary in Europe and usually known as alecrim in Brazil [13]. This plant's most recognized pharmacological benefits are identified by its phenolic ingredients: caffeic acid, carnosic acid, rosmarinic acid, and carnosol. As they naturally hold potential antioxidant scavenging effects, carnosol and carnosic acid cover almost $90 \%$ of the antioxidant action of rosemary among the phenolic components [13]. Furthermore, rosemary was used to reduce anxiety and depression and measure memory performance during clinical trials of a group of university students [14]. This natural plant is utilized as a flavouring/odour agents in beverages, food items, and cosmetics [15]. Rosmarinus officinalis L. extract has been proposed as a possible therapeutic agent for many diseases [16]. Rosemary powder and its lyophilized ethanolic extract at different concentrations were used to formulate fresh cheeses, wherein the plant extract improved phenolics content and antioxidant capacity compared to the control cheese [17]. This study focused on enhancing the functional properties of yoghurt with the addition of different concentrations of rosemary extracts.

\section{Materials and Methods}

Buffalo milk (4.5\% protein and $7.0 \%$ fat) samples were collected from the local markets and properly stored in the icebox to maintain the temperature at $4{ }^{\circ} \mathrm{C}$. The percent of milk samples' fat, solids-not-fat (SNF), protein, lactose, density, freezing point, and minerals were determined. The other ingredient, rosemary, was obtained from a medicinal herb garden. One probiotic bacteria Bifidobacterium longum ATCC15707 (American Type Culture Collection (ATCC)), two lactic acid bacteria Lactobacillus delbrueckii subsp. bulgaricus, and Streptococcus thermophilus (Sassenage-France) were mixed by 1:1 ratio.

\subsection{Preparation of Rosemary Aqueous Extract}

Rosemary aqueous extract was prepared by the method followed by Abdelfadel and Khalaf [18]. Rosemary sample (25 g) was washed initially using normal tap water, then washed again with distilled water and stored at room temperature, then blended with an electric blender (Vitamix, Black A3300 Ascent Series Smart Blender, Cleveland, OH, 
USA). Afterward, the rosemary sample was put into a conical flask and extracted with distilled water $(100 \mathrm{~mL})$ for $24 \mathrm{~h}$ on a vibrator water bath at the three different extraction temperatures of $20^{\circ} \mathrm{C}, 40{ }^{\circ} \mathrm{C}$, and $60^{\circ} \mathrm{C}$. In the next step aqueous rosemary extract was centrifuged at $3000 \mathrm{rpm}$ for $10 \mathrm{~min}$ and the aqueous extract was filtered using Whatman filter paper (GF/A, $110 \mathrm{~mm}$ ). After that, the extract was filtered of microbes through a Millipore filter extract ( $0.22 \mu \mathrm{m}$ micro-filters, Merck \& Co., Inc., Darmstadt, Germany) into $10 \mathrm{~mL}$ tubes and kept at $-20^{\circ} \mathrm{C}$ until further usage [19].

\subsection{Determination of Total Phenolic Content}

The total phenolic content (TPC) was estimated by the Folin-Ciocalteau method [20]. We mixed $0.4 \mathrm{~mL}$ of the extract in methanol $(1 \mathrm{mg} / \mathrm{mL})$ with $2 \mathrm{~mL}$ of Folin-Ciocalteau reagent and $1.6 \mathrm{~mL}$ of $(7 \%)$ sodium carbonate. After that, all the samples were shaken gently and placed in a dark place for $90 \mathrm{~min}$. The absorbance of the samples was measured at $750 \mathrm{~nm}$ using a spectrophotometer (Shimadzu-UV-160, Shimadzu Research Laboratory Co. Ltd., Tokyo, Japan). Gallic acid monohydrate was used to prepare a standard curve. The TPC was calculated and the result was expressed as mg GAE/g extract.

\subsection{Determination of Antioxidant Activity}

Antioxidant activity of the extracted rosemary samples at the three different temperatures of $20^{\circ} \mathrm{C}, 40{ }^{\circ} \mathrm{C}$, and $60^{\circ} \mathrm{C}$ was estimated depending on free radical scavenging activity using 2, 2-diphenyl-1-picrylhydrazyl (DPPH) radical according to the method suggested by Moo-Huchin [21], where the result is expressed as percentage (\%) inhibition.

\subsection{Minerals Analysis}

The rosemary samples extracted at $60^{\circ} \mathrm{C}$ were filtered through filter paper $(0.45 \mu \mathrm{m})$ into a $25 \mathrm{~mL}$ volumetric flask and completed to the mark with deionized water. Samples were taken for elemental analysis on the ICP-OES (Model 5100 VDV Agilent) [22].

\subsection{Determination of Amino Acid Content}

The rosemary samples extracted at $60^{\circ} \mathrm{C}$ were prepared as per the method of Hwang et al. [23]. Each of the defatted samples $(200 \mathrm{mg}$ ) were weighed into a glass ampoule and $5 \mathrm{~mL}$ of $6 \mathrm{~N}$ $\mathrm{HCl}$ was added. After that, the glass ampoule contents were hydrolyzed in an electric oven preset at $105^{\circ} \mathrm{C}$ for $22 \mathrm{~h}$. Oxygen was expelled into the ampoule by passing nitrogen gas into it. Amino acid analysis was undertaken using an amino acid analyzer (Sykam S 433, Shanghai, China). The analysis was carried out with a gas flow rate of $0.5 \mathrm{~mL} / \mathrm{min}$ at $60^{\circ} \mathrm{C}$, and the reproducibility rate was $3 \%$. The amino acid composition was calculated from the integrated areas of standards peaks and expressed as percentages of the total protein.

\subsection{Determination of Fatty Acid Composition}

Fatty acid (FA) composition was determined for the rosemary samples extracted at $60^{\circ} \mathrm{C}$. Lipid extraction of the samples was performed according to Pratap-Singh et al. [24]. The extract was expressed as crude fat and used for the trans-methylation of the FAs. The FA methyl esters in hexane were then injected into a gas chromatograph (ACME model 610 GC (Young LTN Instrument Co., Anyang, Korea) equipped with a flame ionization detector. The separation of the FA methyl esters was performed using a Famewax ${ }^{\mathrm{TM}}$ fused silica capillary column $(30 \mathrm{~m} \times 0.25 \mathrm{~mm}$ (i.d.), $0.25 \mu \mathrm{m})$ (Restek Corporation, Bellefonte, PA, USA). The peak area was measured using a Dani Data Station DDS 1000. Each peak was identified and quantified on the basis of pure methyl ester standards (Restek Corporation, Bellefonte, PA, USA). All analyses were performed in triplicate.

\subsection{High-Performance Liquid Chromatography (HPLC) Analysis of Phenolic Compounds of Extracts}

The phenolic compounds of the extracted rosemary at $60{ }^{\circ} \mathrm{C}$ were determined using Agilent 1260 Infinity HPLC series (Agilent, Santa Clara, CA, USA), equipped with a quaternary pump, a Zorbax Eclipse Plus C18 column $100 \mathrm{~mm} \times 4.6 \mathrm{~mm}$ i.d., (Agilent 
Technologies, Santa Clara, CA, USA) operated at $25{ }^{\circ} \mathrm{C}$ was used for phenolic compound analysis. The injected volume was $20 \mu$. VWD detector set at $284 \mathrm{~nm}$. The separation was achieved using a ternary linear elution gradient with (a) $\mathrm{HPLC}$-grade water $0.2 \% \mathrm{H}_{3} \mathrm{PO}_{4}$ $(v / v),(b)$ methanol, and (c) acetonitrile [25].

\subsection{Preparation of Symbiotic Yoghurt}

Symbiotic yoghurt was manufactured by pasteurized buffalo's milk $\left(15 \mathrm{~min} / 85^{\circ} \mathrm{C}\right)$. then it was cooled down to $42{ }^{\circ} \mathrm{C}$. and then $2 \% w / v$ starter culture (Streptococcus thermophilus and Lactobacillus delbrueckii subsp. Bulgaricus) was added at $42{ }^{\circ} \mathrm{C}$ and later on, Bifidobacterium longum ATCC1570 $(2 \% w / v)$ was added at the same temperature. The extracted rosemary at $60{ }^{\circ} \mathrm{C}$ was added to the pasteurized buffalo milk at concentrations of $0,1.5 \%, 2.0 \%, 2.5 \%$, and $3.0 \%(w / v)$ according to the study of Ehsani [26], then incubated for $3 \mathrm{~h}$ at $42{ }^{\circ} \mathrm{C}$. The yoghurt fortified with different concentration of rosemary extract was stored for $\left(0,7\right.$, and 14 days) at $5{ }^{\circ} \mathrm{C}$. The T1, T2, T3 and T4 were yoghurt fortified with $1.5 \%, 2.0 \% 2.5 \%$ and $3.0 \%$ of Rosmarinus officinalis L. aqueous extract, respectively.

\subsection{Chemical Analysis}

Total solids, protein, fat and ash content, and $\mathrm{pH}$ value were determined as described by official methods of analysis of AOAC, (2007) [27]. Titratable acidity was evaluated based on Richardson's study [28].

\subsection{Microbiological Analysis}

The total bacteria count was determined by making a serial dilution to $10 \mathrm{of} 1 \mathrm{~g}$ of each sample of yogurt. Thereafter, $0.1 \mathrm{~mL}$ of each dilution of yoghurt sample was placed on nutrient agar plates and incubated at $35^{\circ} \mathrm{C}$ for $48 \mathrm{~h}$. The same procedure was used for counting coliform bacteria and Staphylococcus aureus, except that nutrient agar was replaced with MacConkey agar and Mannitol Salt Agar, and all Petri dishes were incubated at $37^{\circ} \mathrm{C}$. Lipolytic bacteria were calculated using Tributyrin Agar (Himedia, Maharashtra, India) and incubated at a temperature of $7^{\circ} \mathrm{C}$ for 10 days. The proteolytic bacteria count was enumerated using Caseinate Agar (Himedia, Maharashtra, India) and then incubated at $7^{\circ} \mathrm{C}$ for 10 days. B. longum were calculated using MRS-NNLP Agar (Himedia, Maharashtra, India) and incubated at a temperature of $37^{\circ} \mathrm{C}$ for $72 \mathrm{~h}$ in anaerobic conditions. $S$. thermophilus were calculated using M17-Agar (Himedia, Maharashtra, India) and incubated at a temperature of $37^{\circ} \mathrm{C}$ for a period of $72 \mathrm{~h}$ in aerobic conditions. Lactobacillus delbruekii ssp. Bulgaricus were enumerated using MRS-Agar (Himedia, Maharashtra, India) and incubated at $37^{\circ} \mathrm{C}$ for $72 \mathrm{~h}$ in anaerobic conditions. The total number of yeasts and molds was determined according to the method described by Harrigan and MacCane [29].

\subsection{Sensory Evaluation of Symbiotic Yoghurt}

Ten well-trained and experienced panelists participated in the sensory evaluation, in which they evaluated the texture, flavor, appearance and color of the yogurt samples. All the panelists evaluated carefully and scored their responses on a scale of 40 points for texture and 40 points for flavor, 10 points for appearance and 10 points for color [30].

\subsection{Statistical Analysis}

All the experimental data obtained (means of three replicates) were statistically analyzed by one-way analysis of variance (ANOVA test) using SPSS ${ }^{\circledR} 13.0$ (Statistical Package for the Social Sciences) (2005). Statistical differences were considered significant at $(p \leq 0.05)$. 


\section{Results and Discussion}

3.1. Effect of Extraction Temperature on the Phenolic Content and Antioxidant Activity of Rosemary Extract

The phenolic content of rosemary plant extracts increased from 85 to $90 \mathrm{mg}$ GAE/g as the extraction temperature increased from $20^{\circ} \mathrm{C}$ to $60^{\circ} \mathrm{C}$, respectively (Figure 1a). There was a statistically significant difference $(p<0.05)$ between the amount of total phenolic content extracted from the rosemary plant at different temperatures. The corresponding antioxidant activity of rosemary plant extracts also increased from $15 \%$ to $18 \%$ as extraction temperatures increased from $20^{\circ} \mathrm{C}$ to $60^{\circ} \mathrm{C}$, respectively (Figure $1 \mathrm{~b}$ ).
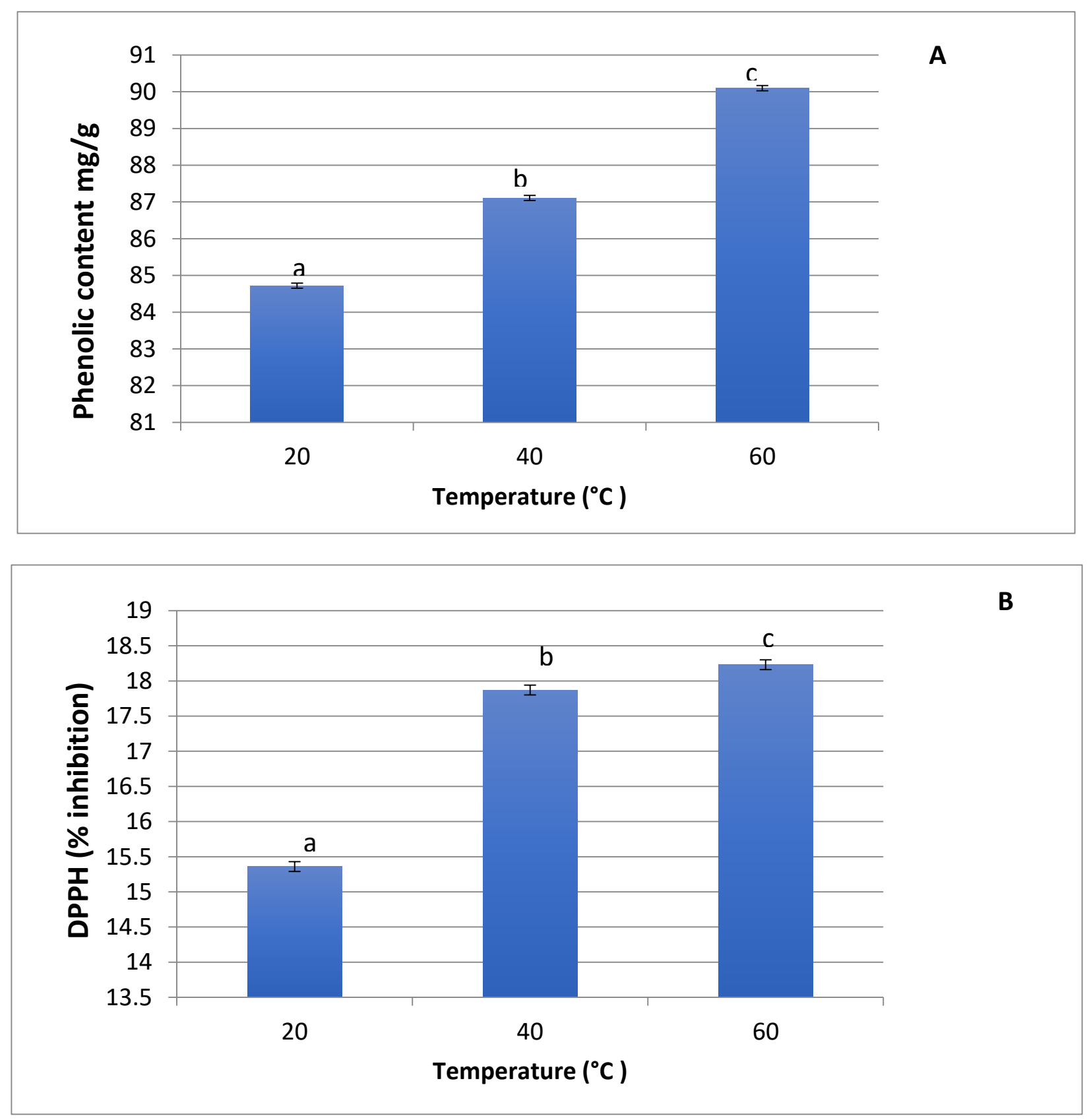

Figure 1. (A) The total phenolic content and (B) antioxidant activity of rosemary plant extracts (a-c denotes means with same letters are not statistically significant $p>0.05)$. 
Obtaining a higher quantity of phenolic compounds during high temperatures indicated the ability of temperatures and their efficiency to extract the multiple phenolic compounds. According to Erkan [31], when comparing rosemary extract and blackseed essential oil, the rosemary extract was found to have a higher phenolic content than blackseed essential oil in all three test methods applied in their experiment. Gomaa [19] found that aqueous extract of rosemary plant showed higher phenolic content $(104.99 \mathrm{mg} \mathrm{GAE} / \mathrm{g}$ extract) than other plant extracts studied including dill, garlic, flaxseeds, and oat were extracted by water solvent. Furthermore, the total phenolic compound of rosemary plant extract extracted by ethanolic (10\% dimethylsulfoxide; DMSO) extract exhibited a lower value (46.89 mg GAE/g extract) than aqueous extracted rosemary extract. Our study results provided evidence that rosemary aqueous extract contained a substantial amount of total phenolic compounds, agreeing with another prior study of Khalil and Gomaa [32].

Our results confirm the utilization of $60^{\circ} \mathrm{C}$ as the extraction temperatures for further parts of this study. One may argue that a higher temperature than $60^{\circ} \mathrm{C}$ may be utilized, however, a higher temperature than $60^{\circ} \mathrm{C}$ is generally not preferred as the high temperature adversely affect the phenolic and antioxidant content [33] more than their ability to increase extraction efficiency. Trojakova's study [34] indicated that the rosemary extract showed higher antioxidant activity under the test conditions at $40{ }^{\circ} \mathrm{C}$ or $60{ }^{\circ} \mathrm{C}$ than the temperature at $100{ }^{\circ} \mathrm{C}$. Another research work [35] revealed that the extraction of polyphenolic compounds from rosemary extract was the most efficient at the extraction temperature of $60^{\circ} \mathrm{C}$ compared to $70^{\circ} \mathrm{C}$ and $90^{\circ} \mathrm{C}$. This confirms that moderate temperature $\left(60^{\circ} \mathrm{C}\right)$ was enough to extract phenolic compounds that have antioxidant activity and thus give a significantly higher efficacy.

\subsection{Characterization of the Rosemary Aqueous Extract Extracted at $60^{\circ} \mathrm{C}$}

In terms of mineral composition, the rosemary extract contained different macro-elements such as sodium, potassium, calcium, phosphorus, magnesium, and micro-elements for instance, iron, copper, manganese, zinc etc. Among the identified macro-elements, the content of potassium was the highest and the lowest amount was observed in magnesium. For micro-elements, the highest quantity was reported for Iron, and copper content was the least (Table 1). The study result was almost similar to the Boix et al. [35] where the growth and development of Rosmarinus officinalis plants occurred under the specified conditions and Daghestani et al. [36]. The rosemary extract contained both the essential amino acids (EAAs) and non-essential amino acids (NEAAs), including histidine, isoleucine, leucine, lysine, Table 1 shows the percentage of amino acids in the rosemary plant extract, as the extract contained the amino acids Histidine, Isoleucine, Leucine, and Liysine.

Methionine, phenylalanine, threonine, tyrosine, valine, alanine, and arginine. The quantity of phenylalanine (11.61) was the maximum and the methionine (1.81) had the minimum volume among all the essential acids. The study results were similar to those obtained by Peixoto et al. [37]. Respectively, the results obtained were similar to those obtained.

The rosemary extract also contained fatty acids comprising myristic acid, palmitic acid, palmitoleic, stearic acid, oleic acid, linoleic acid, Linolenic acid, arachidic acid, gondoic acid, and behenic acid,. This study result also exhibited that the amount of unsaturated fatty acid (75.54 g) was higher than the saturated fatty acid (24.65 g) and the results were similar to the result found in the Popescu experiment [38]. 
Table 1. (a) Phenolic composition, (b) mineral (elemental) composition, (c) amino-acid profile and (d) fatty acid profile of Rosmarinus officinalis L. extract.

\begin{tabular}{|c|c|}
\hline (a) Phenolic Compounds & Conc. $(\mathrm{mg} / 100 \mathrm{~g})^{1}$ \\
\hline Gallic acid & $4.31 \pm 0.480$ \\
\hline Catechol & $1474.25 \pm 5.833$ \\
\hline P-Hydroxy benzoic acid & $309.65 \pm 1.661$ \\
\hline Caffeine & $235.66 \pm 2.361$ \\
\hline Vanillic acid & $64.38 \pm 1.103$ \\
\hline Caffeic acid & $\mathrm{ND}^{2}$ \\
\hline Syringic acid & $13.00 \pm 0.636$ \\
\hline Vanillin & $9.38 \pm 0.791$ \\
\hline p- Coumaric acid & $3.18 \pm 0.643$ \\
\hline Ferulic acid & $4.91 \pm 0.127$ \\
\hline Rutin & $54.25 \pm 0.579$ \\
\hline Ellagic acid & $42.49 \pm 0.360$ \\
\hline Benzoic acid & $\mathrm{ND}^{2}$ \\
\hline O-Coumaric acid & $232.31 \pm 1.124$ \\
\hline Salicylic acid & $271.54 \pm 1.025$ \\
\hline Cinnamic acid & $14.26 \pm 0.678$ \\
\hline (b)Minerals & Conc.(mg/100 g) ${ }^{1}$ \\
\hline \multicolumn{2}{|c|}{ Macro-elements } \\
\hline Sodium $(\mathrm{Na})$ & $92.31 \pm 0.577$ \\
\hline Potassium (K) & $2035.51 \pm 3.89$ \\
\hline Calcium (Ca) & $1246.35 \pm 4.49$ \\
\hline Phosphorus (P) & $477.29 \pm 5.51$ \\
\hline Magnesium (Mg) & $45.95 \pm 1.05$ \\
\hline \multicolumn{2}{|c|}{ Micro-elements } \\
\hline Iron $(\mathrm{Fe})$ & $45.36 \pm 1.09$ \\
\hline Copper $(\mathrm{Cu})$ & $0.59 \pm 0.05$ \\
\hline Manganese (Mn) & $4.59 \pm 0.88$ \\
\hline Zinc $(\mathrm{Zn})$ & $7.42 \pm 0.98$ \\
\hline (c)Amino acids & Conc.(mg/100 g) ${ }^{1}$ \\
\hline \multicolumn{2}{|c|}{ Essential Amino Acids (EAAs) } \\
\hline Histidine & $4.19 \pm 0.43$ \\
\hline Isoleucine & $2.92 \pm 0.29$ \\
\hline Leucine & $5.82 \pm 0.53$ \\
\hline Lysine & $5.79 \pm 0.12$ \\
\hline Methionine & $1.81 \pm 0.09$ \\
\hline Phenylalanine & $11.61 \pm 0.36$ \\
\hline Threonine & $2.62 \pm 0.09$ \\
\hline Tyrosine & $4.92 \pm 0.32$ \\
\hline Valine & $4.82 \pm 0.29$ \\
\hline \multicolumn{2}{|c|}{ Non-essential Amino Acids (NEAAs) } \\
\hline Alanine & $5.88 \pm 0.63$ \\
\hline Arginine & $4.04 \pm 0.11$ \\
\hline (d)Fatty acids & Conc.(mg/100 g) ${ }^{1}$ \\
\hline Myristic acid (C14:0) & $3.48 \pm 0.36$ \\
\hline Palmitic acid (C16:0) & $15.36 \pm 0.91$ \\
\hline Palmitolic (C16:1) & $3.79 \pm 0.38$ \\
\hline Stearic acid (C18:0) & $4.36 \pm 0.44$ \\
\hline Oleic acid (C18:1) & $41.67 \pm 1.12$ \\
\hline Linoleic acid (C18:2) & $7.57 \pm 0.85$ \\
\hline Linolenic acid (C18:3) & $18.87 \pm 1.09$ \\
\hline Arachidic acid (C20:0) & $0.84 \pm 0.07$ \\
\hline Gondoic acid (C20:1) & $4.48 \pm 0.54$ \\
\hline Behenic acid (C22:0) & $0.84 \pm 0.09$ \\
\hline SFA $^{3}$ & $24.65 \pm 0.27$ \\
\hline USFA $^{4}$ & $75.54 \pm 1.08$ \\
\hline $\mathrm{USFA}^{4} / \mathrm{AFA}^{3}$ & $3.23 \pm 0.98$ \\
\hline
\end{tabular}

${ }^{1}$ Values are expressed in $\mathrm{mg} / 100 \mathrm{~g}$ extract as mean \pm standard deviation. ${ }^{2}$ ND: Not Detected. ${ }^{3}$ SFA: Saturated fatty acid; ${ }^{4}$ USFA: Unsaturated fatty acid.

Table 1 describes the chemical composition (phenolic compounds, minerals, amino acids and fatty acids) of the rosemary aqueous extract at $60^{\circ} \mathrm{C}$ temperature. We quantified 14 different phenolic compounds in the rosemary plant extract. Figure 2 shows the 
chromatogram of phenolic compounds in Rosmarinus officinalis L. where 14 phenolic compounds were detected at the wavelength of $284 \mathrm{~nm}$ which included gallic acid (4.1 min), catechol (8.5 $\mathrm{min})$, p-hydroxybenzoic acid (10.0 $\mathrm{min})$, caffeine (10.3 min), vanillic acid (11.5 min), syringic acid (12.3 min), vanillin (13.4 min), p-coumaric acid (15.0 min), ferulic acid (15.5 $\mathrm{min})$, rutin (16.4 $\mathrm{min})$, ellagic (17.0 $\mathrm{min})$, o-coumaric acid (18.4 $\mathrm{min})$, salicylic acid (20.5 min), and cinnamic acid (23.4 min). Amongst all the detected compounds, the quantity of catechol was the highest $(1474.25 \mathrm{mg} / \mathrm{g})$ and the lowest amount $(3.18 \mathrm{mg} / \mathrm{g})$ was p-coumaric acid, while caffeic acid, and benzoic acid were not detected. Other compounds in major concentration (above $200 \mathrm{mg} / \mathrm{g}$ ) identified were p-hydroxy benzoic acid, caffeine, o-coumaric acid, and salicylic acid. A previous study [30] identified 11 different compounds (gallic acid, caffeic acid, ferulic acid, rosmarinic acid, coumaric acid, carnosol, carnosic acid, hesperidin, luteolin, apigenin and genkwanin) in extracts of rosemary plants. Kostikova [39] found 22 phenolic compounds in aqueous ethanolic extracts from Sorbaria pallasii leaves using HPLC analysis. Nour et al. [40] developed an efficient and precise HPLC method to quantify pharmacologically active phenolic compounds such as vanillic, gallic acid, syringic, p-coumaric, ferulic, ellagic, and salcyilic acid in walnut leaves, where the content of ellagic acid was much higher than other phenolic acids. The study result determined the phenolic compounds were similar to the phenolic acids found in our experiment and rosemary extract is capable of showing extensive antioxidant activity like walnut leaves. A study by Gini and Jeya [41] showed that the identification of a number of phenolic compounds, for instance, gallic acid, catechol, and vanillin occurred in the active fractions of ethyl acetate extract of Salvinia molesta and the identified phenolic compounds were found to depict antioxidant activity that was able to reduce or inhibit oxidative damage resulting from free radicals. The outcome of this research study has similar effects to our present study.

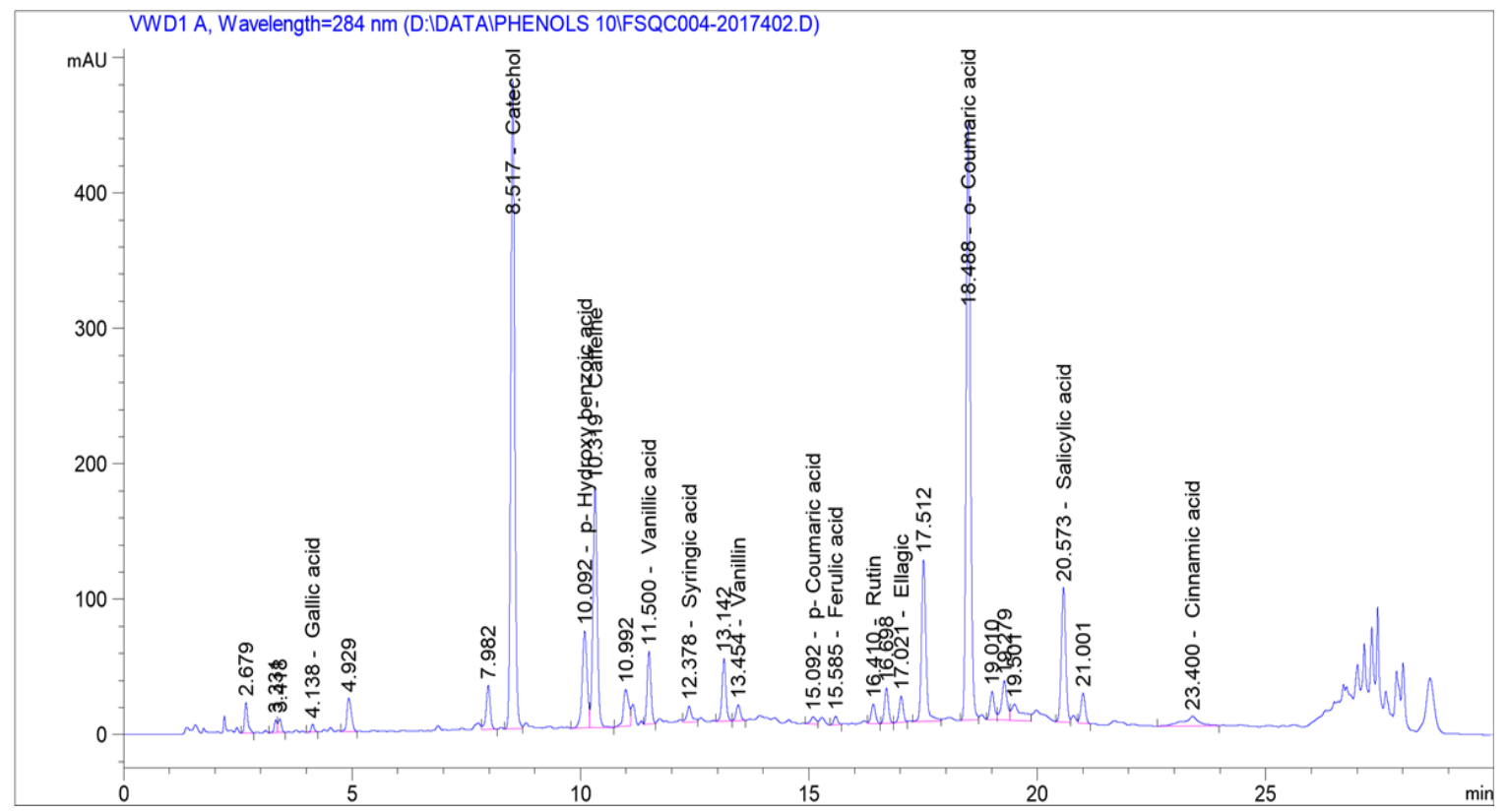

Figure 2. High-performance liquid chromatography (HPLC) chromatogram of phenolic compounds in Rosmarinus officinalis. L. (detection at $284 \mathrm{~nm}$ ). $X$-axis = retention time, $\min =$ minutes; and $Y$-axis = detector signal.

\subsection{Characterization of the Yoghurt Fortified with Rosemary Aqueous Extract}

The chemical composition of yoghurt prepared with different concentrations of rosemary aqueous extract is illustrated in Table 2. The addition of 1.5\%, 2.0\%, 2.5\%, and 3.0\% aqueous extract of rosemary markedly increased the fat, protein, ash content, and increased $\mathrm{pH}$ value of yoghurt of the treatment groups (T1, T2, T3, and T4) compared with the control group during storage time, whereas the moisture content of the control group was 
higher than all treatment groups in days 0,7 , and 14 . Among all the treatment groups, it is noticeable that the moisture content of the samples decreased gradually when the concentrations of rosemary aqueous extract increased proportionally on 0,7 days and also after 14 days of storage. This might be caused by evaporation during storage where the rosemary aqueous extracts probably are not effected by the controlling of moisture of the samples.

Table 2. Chemical composition, $\mathrm{pH}$, and acidity of yoghurt fortified with different concentration of rosemary extract (mean \pm standard deviation) during storage ( 0,7 , and 14 days).

\begin{tabular}{|c|c|c|c|c|c|c|}
\hline Treatment & Storage (Days) & Control & T1 & T2 & T3 & $\mathrm{T} 4$ \\
\hline \multirow{3}{*}{ Moisture (\%) } & 0 & $89.42 \pm 0.07^{\mathrm{d}}$ & $88.55 \pm 0.07^{\mathrm{cd}}$ & $87.67 \pm 0.07^{b c}$ & $86.83 \pm 0.07^{a b}$ & $85.52 \pm 0.07^{a}$ \\
\hline & 7 & $89.13 \pm 0.07^{\mathrm{d}}$ & $88.24 \pm 0.07^{\mathrm{cd}}$ & $87.48 \pm 0.07^{\mathrm{cd}}$ & $86.63 \pm 0.07^{a b}$ & $85.26 \pm 0.07^{\mathrm{a}}$ \\
\hline & 14 & $88.27 \pm 0.07^{\mathrm{d}}$ & $87.85 \pm 0.07^{\mathrm{cd}}$ & $86.77 \pm 0.07 \mathrm{~cd}$ & $85.80 \pm 0.07^{a b}$ & $84.72 \pm 0.07^{a}$ \\
\hline \multirow{3}{*}{ Fat $(\%)$} & 0 & $6.49 \pm 0.07^{\mathrm{d}}$ & $6.54 \pm 0.07^{\mathrm{cd}}$ & $6.60 \pm 0.07 \mathrm{bc}$ & $6.70 \pm 0.07^{\mathrm{ab}}$ & $6.77 \pm 0.07^{\mathrm{a}}$ \\
\hline & 7 & $6.52 \pm 0.07^{\mathrm{d}}$ & $6.56 \pm 0.07^{\mathrm{cd}}$ & $6.65 \pm 0.07^{\mathrm{cd}}$ & $6.73 \pm 0.07^{\mathrm{ab}}$ & $6.79 \pm 0.07^{\mathrm{a}}$ \\
\hline & 14 & $6.53 \pm 0.07^{\mathrm{d}}$ & $6.57 \pm 0.07^{\mathrm{cd}}$ & $6.67 \pm 0.07^{\mathrm{cd}}$ & $6.75 \pm 0.07^{\mathrm{ab}}$ & $6.82 \pm 0.07^{\mathrm{a}}$ \\
\hline \multirow{3}{*}{ Protein $(\%)$} & 0 & $4.35 \pm 0.03^{\mathrm{d}}$ & $4.41 \pm 0.03^{c d}$ & $4.45 \pm 0.03 \mathrm{bc}$ & $4.51 \pm 0.03 \mathrm{ab}$ & $4.57 \pm 0.03^{\mathrm{a}}$ \\
\hline & 7 & $4.37 \pm 0.03^{\mathrm{d}}$ & $4.42 \pm 0.03^{\mathrm{cd}}$ & $4.48 \pm 0.03 \mathrm{bc}$ & $4.53 \pm 0.03^{\mathrm{ab}}$ & $4.59 \pm 0.03^{\mathrm{a}}$ \\
\hline & 14 & $4.39 \pm 0.03^{\mathrm{d}}$ & $4.44 \pm 0.03^{\mathrm{cd}}$ & $4.50 \pm 0.03^{b c}$ & $4.56 \pm 0.03^{\mathrm{ab}}$ & $4.61 \pm 0.03^{a}$ \\
\hline \multirow{3}{*}{ Ash (\%) } & 0 & $0.60 \pm 0.04^{\mathrm{d}}$ & $0.64 \pm 0.04^{\mathrm{cd}}$ & $0.69 \pm 0.04^{b c}$ & $0.73 \pm 0.04^{\mathrm{ab}}$ & $0.79 \pm 0.04^{\mathrm{a}}$ \\
\hline & 7 & $0.62 \pm 0.04^{\mathrm{d}}$ & $0.65 \pm 0.04 \mathrm{~cd}$ & $0.71 \pm 0.04 \mathrm{bc}$ & $0.75 \pm 0.04^{\mathrm{ab}}$ & $0.81 \pm 0.04^{\mathrm{a}}$ \\
\hline & 14 & $0.63 \pm 0.04^{\mathrm{d}}$ & $0.67 \pm 0.04^{\mathrm{cd}}$ & $0.72 \pm 0.04^{b c}$ & $0.77 \pm 0.04^{\mathrm{ab}}$ & $0.82 \pm 0.04^{\mathrm{a}}$ \\
\hline \multirow{3}{*}{$\mathrm{pH}$ value } & 0 & $4.62 \pm 0.02^{\mathrm{a}}$ & $4.63 \pm 0.02^{\mathrm{a}}$ & $4.65 \pm 0.02^{\mathrm{a}}$ & $4.70 \pm 0.02^{\mathrm{a}}$ & $4.75 \pm 0.02^{\mathrm{a}}$ \\
\hline & 7 & $4.58 \pm 0.02^{\mathrm{a}}$ & $4.60 \pm 0.02^{\mathrm{a}}$ & $4.62 \pm 0.02^{\mathrm{a}}$ & $4.66 \pm 0.02^{\mathrm{a}}$ & $4.70 \pm 0.02^{\mathrm{a}}$ \\
\hline & 14 & $4.56 \pm 0.02^{\mathrm{a}}$ & $4.59 \pm 0.02^{\mathrm{a}}$ & $4.60 \pm 0.02^{\mathrm{a}}$ & $4.62 \pm 0.02^{\mathrm{a}}$ & $4.68 \pm 0.02^{\mathrm{a}}$ \\
\hline \multirow{3}{*}{ Titration Acidity } & 0 & $0.9 \pm 0.01^{\mathrm{a}}$ & $0.89 \pm 0.01^{\mathrm{a}}$ & $0.86 \pm 0.01^{\mathrm{a}}$ & $0.81 \pm 0.01^{\mathrm{a}}$ & $0.75 \pm 0.01^{\mathrm{a}}$ \\
\hline & 7 & $0.92 \pm 0.01^{\mathrm{a}}$ & $0.91 \pm 0.01^{\mathrm{a}}$ & $0.9 \pm 0.01^{\mathrm{a}}$ & $0.86 \pm 0.01^{\mathrm{a}}$ & $0.81 \pm 0.01^{\mathrm{a}}$ \\
\hline & 14 & $0.94 \pm 0.01^{\mathrm{a}}$ & $0.92 \pm 0.01^{\mathrm{a}}$ & $0.91 \pm 0.01^{\mathrm{a}}$ & $0.89 \pm 0.01^{\mathrm{a}}$ & $0.83 \pm 0.01^{\mathrm{a}}$ \\
\hline
\end{tabular}

T1: yoghurt fortified with $1.5 \%$ of Rosmarinus officinalis L. aqueous extract. T2: yoghurt fortified with $2.0 \%$ of Rosmarinus officinalis L. aqueous extract. T3: yoghurt fortified with $2.5 \%$ of Rosmarinus officinalis L. aqueous extract. T4: yoghurt fortified with $3.0 \%$ of Rosmarinus officinalis L. aqueous extract. ${ }^{\text {a-d }}$ Means with same superscripts across a row are not significantly different $p>0.05$.

The fat content of treatment groups showed a gradual rise with the increase of their concentrations compared to the control group and the highest percentages of fat content observed in all the treatment groups including the control group after 14 days of preservation. There were no statistically significant differences $(p>0.05)$ between rosemary treatment groups and the control group.

The protein content of yoghurt treatments which include T1, T2, T3, and T4 were $4.41 \%, 4.45 \%, 4.51 \%$, and $4.57 \%$, respectively, in 0 days, and the percentages of protein content were attained maximal after 14 days of storage compared to 0 days and 7 days storage. The explanation for this rise can be attributed to the continued decrease in the moisture content of the yoghurt during storage times. There was no statistically significant difference $(p>0.05)$ in this study among the control and treatment groups.

Likewise with the protein content, there was an increase exhibited in the ash content of all yoghurt treatments after finishing 14 days storage timeframe without statistically significant differences $(p>0.05)$. After 14 days preservation, the ash content were also reached maximum in all the treatment groups including control group. The ash content of the samples was increased moderately when the concentrations of rosemary aqueous extract increased proportionally. Ash content has been affected by the addition of rosemary aqueous extracts in the yoghurt samples compared to the control one.

The $\mathrm{pH}$ values were low for all the treatment groups and control groups after 14 days of storage; however, the treatment groups' $\mathrm{pH}$ value was higher than the control group. Joung [42] also found that the $\mathrm{pH}$ values of all yoghurt treatments were decreased during the 14 days of storage and the $\mathrm{pH}$ reduction during storage also could be the cause of lactose conversion into lactic acid in storage time [43]. The rosemary aqueous extracts 
mixed treatment groups restricted the bacterial growth of yoghurt and subsequently kept $\mathrm{pH}$ higher than the $\mathrm{pH}$ of a control group.

The titratable acidity of all the treatments and control samples were determined after storing at a temperature of $4{ }^{\circ} \mathrm{C}$ for a period of 0,7 , and 14 days (Table 2). There was no statistically significant difference in the titration acidity of all the studied samples with the progress of the storage periods. In the titration acidity study, it was noticed that the titration acidity values of the control samples were higher compared to all treatment groups of samples. This may be the reason why the different treatment groups containing different concentrations of rosemary extracts caused partial or complete inactivation of some microorganisms, especially for Gram-positive bacteria by absorbing rosemary extracts that affect the bacterial cell surface. Gorissen et al. [44] found that the permeability of the cytoplasm membrane to bacteria was increased at $4{ }^{\circ} \mathrm{C}$ temperature with the presence of extracts. Another study by Smith-Palmer [45] also indicated the ability of the plant extracts in the produced yogurt to form a protective layer (coat around bacterium) against microorganisms, as it caused an obstruction to the transfer of the active compounds in the plant extracts added to the active or inactive sites in the bacteria due to the low and restricted water content of the product. Moreover, $\mathrm{Xu}$ [46] state that the refrigerator temperature does not affect the growth of lactic acid bacteria.

Table 3 represents the total number of bacteria, coliform bacteria, Staphylococcus aureus, lipolytic bacteria, proteolytic bacteria, molds, and yeasts in the stored yogurt samples at $5{ }^{\circ} \mathrm{C}$ for 0,7 , and 14 days storage. Total bacterial count increased from $6.18 \mathrm{CFU} / \mathrm{gm}$ yogurt in 0 days to $8.16 \mathrm{CFU} / \mathrm{g}$ yoghurt after 14 days for control samples where all the treatment group of samples showed the lower total bacteria count compared to the control on the 14th day. The control samples showed a higher coliform content compared to other yogurt treatments. As the storage days progressed, it was clearly observed that the control group had the highest bacterial concentration and with an increase in the concentration of rosemary extract, the coliform bacterium content was gradually decreased. In terms of Staphylococcus aureus, there was no bacterial production in the treatment groups after both 0 and 7 days however, the production of Staphylococcus aureus reached up to $3.07 \mathrm{CFU} / \mathrm{gm}$ after 7 days storage in the control samples. However, the content of Staphylococcus aureus was higher (3.43 CFU/gm) in the control group compared to all the rosemary mixed treatment groups. Considering the preparation of lipolytic bacteria and proteolytic bacteria, there were no noticeable differences between the different transactions and storage periods. In 0 days, no lipolytic and proteolytic bacteria were formed in the control samples; however, the numbers of bacteria reached the maximum level at the 14 days. For rosemary treatment groups, the bacteria numbers were decreased markedly after 14 days of storage because of the effects of rosemary aqueous extract. The rosemary extract also positively affected the total numbers of yeasts and molds, as the storage periods of 0 and 7 days did not provide any fungal growth for all the studied samples. After 7 days, the control samples showed fungal growth and the yeast and mold numbers reached $2.32 \mathrm{CFU} / \mathrm{gm}$ at the 14 days, while the treatment groups experienced a low level of fungal growth and $1.30 \mathrm{CFU} / \mathrm{gm}$ was the lowest for T4 among all the treatments. On the other hand, the rosemary extract also had a negative effect on the total number of probiotic bacteria (Bifidobacterium longum) and the starter culture (L. bulgaricus and S. thermophilus). The probiotic strain and the starter culture did not show the same stability during storage. 
Table 3. Log of the total bacterial, coliform, Staphylococcus aureus, lipolytic, proteolytic, fungi, and molds in yogurt (mean \pm standard deviation).

\begin{tabular}{|c|c|c|c|c|}
\hline \multirow{2}{*}{ Sample } & \multirow{2}{*}{ Microbial Content Bacterial Species } & \multicolumn{3}{|c|}{ Bacterial Count over the Storage Period (Day) } \\
\hline & & 0 Day & 7 Day & 14 Day \\
\hline \multirow{10}{*}{ Control } & Total count bacteria & $6.18 \pm 0.06^{a, x}$ & $7.12 \pm 0.02^{b, x}$ & $8.16 \pm 0.19^{c, x}$ \\
\hline & Coliform & - & $2.39 \pm 0.07^{a, x}$ & $3.96 \pm 0.16^{b, x}$ \\
\hline & S. aureus & - & $3.07 \pm 0.07 \mathrm{~b}, \mathrm{x}$ & $3.43 \pm 0.01^{\mathrm{a}, \mathrm{x}}$ \\
\hline & Lipolytic bacteria & - & $2.04 \pm 0.01^{\mathrm{a}, \mathrm{x}}$ & $3.43 \pm 0.01 \mathrm{~b}, \mathrm{x}$ \\
\hline & Proteolytic bacteria & - & $2.14 \pm 0.03^{a, x}$ & $3.33 \pm 0.03^{b, x}$ \\
\hline & Yeasts and molds & - & $1.69 \pm 0.03^{\mathrm{a}, \mathrm{x}}$ & $2.32 \pm 0.04^{b, x}$ \\
\hline & L. bulgaricus & $6.40 \pm 0.01^{b, x}$ & $5.90 \pm 0.03^{b, x}$ & $5.44 \pm 0.02^{a, x}$ \\
\hline & S. thermophilus & $6.12 \pm 0.02^{b, x}$ & $6.12 \pm 0.02 \mathrm{~b}, \mathrm{x}$ & $5.24 \pm 0.02^{\mathrm{a}, \mathrm{x}}$ \\
\hline & B. longum & $8.90 \pm 0.02^{b, x}$ & $8.71 \pm 0.02^{b, x}$ & $8.18 \pm 0.03^{a, x}$ \\
\hline & Total count bacteria & $6.18 \pm 0.06^{\mathrm{a}, \mathrm{x}}$ & $6.55 \pm 0.04 \mathrm{~b}, \mathrm{y}$ & $6.69 \pm 0.06^{b, y}$ \\
\hline \multirow{5}{*}{$\mathrm{T} 1$} & Coliform & - & $2.26 \pm 0.01 \mathrm{a}, \mathrm{y}$ & $2.56 \pm 0.05^{b, y}$ \\
\hline & S. aureus & - & $1.34 \pm 0.05^{\mathrm{a}, \mathrm{y}}$ & $1.95 \pm 0.04^{b, y}$ \\
\hline & Lipolytic bacteria & - & $2.04 \pm 0.01^{\mathrm{a}, \mathrm{x}}$ & $2.21 \pm 0.01^{\mathrm{a}, \mathrm{y}}$ \\
\hline & Proteolytic bacteria & - & $1.48 \pm 0.01^{\mathrm{a}, \mathrm{y}}$ & $1.91 \pm 0.06^{\mathrm{b}, \mathrm{y}}$ \\
\hline & Yeasts and molds & - & $1.07 \pm 0.02^{\mathrm{a}, \mathrm{y}}$ & $1.32 \pm 0.02^{b, y}$ \\
\hline \multirow{13}{*}{$\mathrm{T} 2$} & L. bulgaricus & $6.14 \pm 0.02^{c, x}$ & $5.84 \pm 0.04^{b, y}$ & $5.35 \pm 0.02^{a, y}$ \\
\hline & S. thermophilus & $6.04 \pm 0.03^{c, x}$ & $5.60 \pm 0.01 \mathrm{~b}, \mathrm{y}$ & $5.22 \pm 0.02^{a, y}$ \\
\hline & B. longum & $8.93 \pm 0.01^{c, x}$ & $8.46 \pm 0.01 b, y$ & $7.98 \pm 0.03^{a, y}$ \\
\hline & Total count bacteria & $6.18 \pm 0.05^{\mathrm{a}, \mathrm{x}}$ & $6.47 \pm 0.03 \mathrm{~b}, y$ & $6.61 \pm 0.01 \mathrm{c}, \mathrm{y}$ \\
\hline & Coliform & - & $2.23 \pm 0.09^{a, y}$ & $2.54 \pm 0.02^{b, y}$ \\
\hline & S. Aureus & - & $1.24 \pm 0.04^{\mathrm{a}}$ & $2.27 \pm 0.02^{b, z}$ \\
\hline & Lipolytic bacteria & - & $2.04 \pm 0.02^{\mathrm{a}}$ & $1.69 \pm 0.04^{b, z}$ \\
\hline & Proteolytic bacteria & - & $1.32 \pm 0.04^{\mathrm{a}}$ & $1.94 \pm 0.03 \mathrm{~b}, \mathrm{y}$ \\
\hline & Yeasts and molds & - & $1.03 \pm 0.02^{\mathrm{a}}$ & $1.31 \pm 0.01^{\mathrm{b}, \mathrm{y}}$ \\
\hline & L. bulgaricus & $6.13 \pm 0.02^{c, x}$ & $5.76 \pm 0.03^{b}$ & $5.31 \pm 0.02^{a, y}$ \\
\hline & S. thermophilus & $6.04 \pm 0.03^{c, x}$ & $5.58 \pm 0.01^{b}$ & $5.12 \pm 0.02^{\mathrm{a}, \mathrm{z}}$ \\
\hline & B. longum & $8.91 \pm 0.02^{c, x}$ & $8.36 \pm 0.03^{b}$ & $7.83 \pm 0.02^{a, y, z}$ \\
\hline & Total count bacteria & $6.18 \pm 0.05^{\mathrm{a}, \mathrm{x}}$ & $6.43 \pm 0.02^{a, y}$ & $6.58 \pm 0.03^{a, y}$ \\
\hline \multirow{6}{*}{$\mathrm{T} 3$} & Coliform & - & $2.13 \pm 0.02^{a, z}$ & $2.52 \pm 0.03^{a, y}$ \\
\hline & S. Aureus & - & $1.24 \pm 0.04^{\mathrm{a}}$ & $2.23 \pm 0.01^{b, z}$ \\
\hline & Lipolytic bacteria & - & $2.05 \pm 0.02^{\mathrm{a}}$ & $1.62 \pm 0.03^{b, z}$ \\
\hline & Proteolytic bacteria & - & $1.36 \pm 0.04^{\mathrm{a}}$ & $1.94 \pm 0.04^{b, y}$ \\
\hline & Yeasts and molds & - & $1.01 \pm 0.02^{\mathrm{a}}$ & $1.33 \pm 0.02^{b, y}$ \\
\hline & L. bulgaricus & $6.12 \pm 0.01^{c, x}$ & $5.71 \pm 0.03^{b}$ & $5.31 \pm 0.02^{a, y}$ \\
\hline \multirow{11}{*}{$\mathrm{T} 4$} & S. thermophilus & $6.03 \pm 0.03^{c, x}$ & $5.57 \pm 0.01^{b}$ & $5.11 \pm 0.02^{\mathrm{a}, \mathrm{z}}$ \\
\hline & B. longum & $8.86 \pm 0.01^{c, x}$ & $8.32 \pm 0.01^{b}$ & $7.74 \pm 0.01^{\mathrm{a}, \mathrm{z}}$ \\
\hline & Total count bacteria & $6.18 \pm 0.045^{\mathrm{a}, \mathrm{x}}$ & $6.33 \pm 0.03^{a, z}$ & $6.43 \pm 0.02^{a, z}$ \\
\hline & Coliform & - & $2.21 \pm 0.01 \mathrm{a}, \mathrm{y}$ & $2.48 \pm 0.04^{b, z}$ \\
\hline & S. Aureus & - & $1.17 \pm 0.04^{\mathrm{a}}$ & $2.21 \pm 0.01^{\text {b.z }}$ \\
\hline & Lipolytic bacteria & - & $2.01 \pm 0.03^{\mathrm{a}}$ & $1.60 \pm 0.02^{b, z}$ \\
\hline & Proteolytic bacteria & - & $1.26 \pm 0.04^{\mathrm{a}}$ & $1.84 \pm 0.01^{\mathrm{b}, \mathrm{z}}$ \\
\hline & Yeasts and molds & - & $1.00 \pm 0.07^{\mathrm{a}}$ & $1.30 \pm 0.03^{b, y}$ \\
\hline & L. bulgaricus & $6.12 \pm 0.01^{c, x}$ & $5.71 \pm 0.03^{b}$ & $5.31 \pm 0.02^{\mathrm{a}, \mathrm{y}}$ \\
\hline & S. thermophilus & $6.04 \pm 0.03^{c, x}$ & $5.53 \pm 0.06^{b}$ & $5.04 \pm 0.03^{\mathrm{a}, \mathrm{z}}$ \\
\hline & B. longum & $8.90 \pm 0.01^{c, x}$ & $8.29 \pm 0.02^{b}$ & $7.62 \pm 0.02^{a, z}$ \\
\hline
\end{tabular}

T1: yoghurt fortified with $1.5 \%$ of Rosmarinus officinalis L. aqueous extract. T2: yoghurt fortified with $2.0 \%$ of Rosmarinus officinalis L. aqueous extract. T3: yoghurt fortified with $2.5 \%$ of Rosmarinus officinalis L. aqueous extract. T4: yoghurt fortified with $3.0 \%$ of Rosmarinus officinalis L. aqueous extract. ${ }^{a-c}$ Means with same superscripts across a row are not significantly different. ${ }^{x-z}$ Means with same superscripts across a microbial type between different treatments are not significantly different $p>0.05$. 


\subsection{Sensory Evaluation of Yoghurt Fortified with Rosemary Aqueous Extract}

Results of sensory evaluation properties of yoghurt revealed that the adding of rosemary as an aqueous extract affected the flavour, body and texture, appearance, and overall acceptance of yoghurt samples (Table 4). In addition, all yoghurt fortified with different concentrations of rosemary aqueous extract had acceptable flavour, body, texture, and appearance scores except the treatment group T4 (for which flavour score was unacceptable). Furthermore, the rosemary extract was used to fortify yoghurt to enhance its nutritional and biological values without any noticeable adverse effect on its acceptability. Ayad et al. [30] observed that the different concentrations of aqueous rosemary extract provided increased health benefits and were acceptable with varying effects on sensory attributes. All yoghurt treatment's sensory evaluation scores were reduced unevenly during the storage period, which might be attributed to lactic acid production and aromatic compounds such as acetone, acetaldehyde, and diacetyl [47]. The amalgamation of probiotic, prebiotic, and aqueous rosemary extract positively affected synbiotic yoghurt treatments' sensory scores. This agrees with the findings of previous researchers that a desirable effect on sensory properties will be gained by using probiotic species in dairy products [48].

Table 4. Sensory evaluation of symbiotic yoghurt fermented milk.

\begin{tabular}{|c|c|c|c|c|c|c|}
\hline Properties & Storage (Day) & Control & T1 & T2 & T3 & $\mathrm{T} 4$ \\
\hline & 0 & 36 & 35 & 35 & 34 & 34 \\
\hline \multirow[t]{2}{*}{ Flavor (40) } & 7 & 34 & 33 & 32 & 32 & 31 \\
\hline & 14 & 33 & 31 & 30 & 29 & 29 \\
\hline \multirow[t]{2}{*}{ Average } & & $34.3 \pm 1.527^{a}$ & $33 \pm 2.08^{a}$ & $32.3 \pm 2.517^{a}$ & $31.6 \pm 2.516^{b}$ & $31.3 \pm 2.516^{b}$ \\
\hline & 0 & 36 & 35 & 35 & 34 & 34 \\
\hline \multirow[t]{2}{*}{ Texture (40) } & 7 & 33 & 32 & 31 & 31 & 30 \\
\hline & 14 & 32 & 30 & 30 & 30 & 29 \\
\hline \multirow[t]{2}{*}{ Average } & & $33.6 \pm 2.081^{\mathrm{a}}$ & $32.3 \pm 2.516^{a}$ & $32 \pm 2.645^{\mathrm{a}}$ & $31.6 \pm 2.081^{b}$ & $31 \pm 2.645^{b}$ \\
\hline & 0 & 7 & 6 & 5 & 4 & 4 \\
\hline \multirow[t]{2}{*}{ Color (10) } & 7 & 6 & 4 & 3 & 2 & 1 \\
\hline & 14 & 6 & 3 & 2 & 2 & 1 \\
\hline \multirow[t]{2}{*}{ Average } & & $6.3 \pm 0.577^{a}$ & $4.3 \pm 1.527^{\mathrm{a}}$ & $3.3 \pm 1.527^{b}$ & $2.6 \pm 1.15^{b}$ & $2 \pm 1.73^{c}$ \\
\hline & 0 & 6 & 5 & 5 & 4 & 4 \\
\hline \multirow[t]{2}{*}{ Appearance (10) } & 7 & 5 & 3 & 2 & 2 & 1 \\
\hline & 14 & 3 & 2 & 1 & 1 & 1 \\
\hline Average & & $4.6 \pm 1.527^{\mathrm{a}}$ & $3.3 \pm 1.527^{\mathrm{a}}$ & $2.6 \pm 2.081^{b}$ & $2.3 \pm 1.527^{b}$ & $2 \pm 1.732^{c}$ \\
\hline
\end{tabular}

${ }^{a-c}$ Means with same superscripts across a row are not significantly different.

\section{Conclusions}

This study revealed that the fortification of yoghurt with the treatment groups T2 and T3 of rosemary aqueous extract showed slightly increased protein, ash, and total solid content; however, they exhibited potential antioxidant activity and held a substantial amount of total phenolic content as well. Furthermore, there was no change in the yogurt's color, taste, and overall acceptability scores for the treatment group T1, whereas the treatment group $\mathrm{T} 4$ showed the lowest overall acceptance among all treatments. There was a good correlation between the total phenolic content and the antioxidant activity, which supports the concept of phenols as contributors to the antioxidant activity of the aqueous extract of rosemary. Previously, scientists conducted very few related studies about adding aqueous rosemary extract in probiotic fermented milk and yogurt to improve its nutrient quality and functional properties. Hence, this study examined the properties of rosemary extracts and suggested the use of an aqueous extract of rosemary as fortified fermented milk via a suitable, cost-effective approach for making products that improve public health. 
Author Contributions: Conceptualization, H.I.A., A.B.A. and A.P.-S.; Data curation, H.I.A. and M.D.; Formal analysis, H.I.A., M.D. and A.P.-S.; Funding acquisition, A.P.-S.; Investigation, H.I.A., A.B.A., A.K.A. and A.P.-S.; Methodology, H.I.A. and M.D.; Project administration, A.B.A., A.K.A. and A.P.-S.; Supervision, A.B.A., A.K.A. and A.P.-S.; Validation, S.J.A.A.; Writing-original draft, H.I.A. and M.D.; Writing-review and editing, S.J.A.A., A.B.A., A.K.A. and A.P.-S. All authors have read and agreed to the published version of the manuscript.

Funding: This research and APC was funded by Natural Science and Engineering Research Council of Canada (NSERC)'s Discovery Grant Award\# RGPIN-2018-04735 to Anubhav Pratap-Singh.

Institutional Review Board Statement: Not applicable.

Informed Consent Statement: Not applicable.

Data Availability Statement: All data are reported in this manuscript.

Acknowledgments: None.

Conflicts of Interest: Authors declare no conflict of interest.

\section{References}

1. Crowe, K.M.; Francis, C. Position of the Academy of Nutrition and Dietetics: Functional Foods. J. Acad. Nutr. Diet. 2013, 113, 1096-1103. [CrossRef]

2. Kaur, N.; Singh, D.P. Retracted: Deciphering the Consumer Behaviour Facets of Functional Foods: A Literature Review. Appetite 2017, 112, 167-187. [CrossRef]

3. Siro, I.; Kápolna, E.; Kápolna, B.; Lugasi, A. Functional Food. Product Development, Marketing and Consumer Acceptance-A Review. Appetite 2008, 51, 456-467. [CrossRef]

4. Ejtahed, H.S.; Mohtadi-Nia, J.; Homayouni-Rad, A.; Niafar, M.; Asghari-Jafarabadi, M.; Mofid, V.; Akbarian-Moghari, A. Effect of Probiotic Yogurt Containing Lactobacillus Acidophilus and Bifidobacterium Lactis on Lipid Profile in Individuals with Type 2 Diabetes Mellitus. J. Dairy Sci. 2011, 94, 3288-3294. [CrossRef]

5. Parvez, S.; Malik, K.A.; Ah Kang, S.; Kim, H. Probiotics and Their Fermented Food Products Are Beneficial for Health. J. Appl. Microbiol. 2006, 100, 1171-1185. [CrossRef]

6. Sanders, M.E. Probiotics: Definition, Sources, Selection, and Uses. Clin. Infect. Dis. 2008, 46 (Suppl. 2), S58-S61. [CrossRef]

7. Lo Presti, M.; Ragusa, S.; Trozzi, A.; Dugo, P.; Visinoni, F.; Fazio, A.; Dugo, G.; Mondello, L. A Comparison between Different Techniques for the Isolation of Rosemary Essential Oil. J. Sep. Sci. 2005, 28, 273-280. [CrossRef] [PubMed]

8. Siejak, P.; Smułek, W.; Fathordobady, F.; Grygier, A.; Baranowska, H.M.; Rudzińska, M.; Masewicz, Ł.; Jarzębska, M.; Nowakowski, P.T.; Makiej, A.; et al. Multidisciplinary Studies of Folk Medicine "Five Thieves' Oil" (Olejek Pięciu Złodziei) Components. Molecules 2021, 26, 2931. [CrossRef]

9. Mohammed, M.J.; Anand, U.; Altemimi, A.B.; Tripathi, V.; Guo, Y.; Pratap-Singh, A. Phenolic Composition, Antioxidant Capacity and Antibacterial Activity of White Wormwood (Artemisia herba-alba). Plants 2021, 10, 164. [CrossRef] [PubMed]

10. Manach, C.; Scalbert, A.; Morand, C.; Rémésy, C.; Jiménez, L. Polyphenols: Food Sources and Bioavailability. Am. J. Clin. Nutr. 2004, 79, 727-747. [CrossRef] [PubMed]

11. Pinela, J.; Prieto, M.A.; Barreiro, M.F.; Carvalho, A.M.; Oliveira, M.B.P.P.; Vázquez, J.A.; Ferreira, I.C.F.R. Optimization of Microwave-Assisted Extraction of Hydrophilic and Lipophilic Antioxidants from a Surplus Tomato Crop by Response Surface Methodology. Food Bioprod. Process. 2016, 98, 283-298. [CrossRef]

12. Dong, M.; He, X.; Liu, R.H. Phytochemicals of Black Bean Seed Coats: Isolation, Structure Elucidation, and Their Antiproliferative and Antioxidative Activities. J. Agric. Food Chem. 2007, 55, 6044-6051. [CrossRef]

13. Mohamed, W.A.M.; Abd-Elhakim, Y.M.; Farouk, S.M. Protective Effects of Ethanolic Extract of Rosemary against Lead-Induced Hepato-Renal Damage in Rabbits. Exp. Toxicol. Pathol. 2016, 68, 451-461. [CrossRef]

14. Nematolahi, P.; Mehrabani, M.; Karami-Mohajeri, S.; Dabaghzadeh, F. Effects of Rosmarinus officinalis L. on Memory Performance, Anxiety, Depression, and Sleep Quality in University Students: A Randomized Clinical Trial. Complement. Ther. Clin. Pract. 2018, 30, 24-28. [CrossRef] [PubMed]

15. Ngo, S.N.T.; Williams, D.B.; Head, R.J. Rosemary and Cancer Prevention: Preclinical Perspectives. Crit. Rev. Food Sci. Nutr. 2011, 51, 946-954. [CrossRef] [PubMed]

16. Prior, R.L.; Cao, G.; Martin, A.; Sofic, E.; McEwen, J.; O’Brien, C.; Lischner, N.; Ehlenfeldt, M.; Kalt, W.; Krewer, G. Antioxidant Capacity as Influenced by Total Phenolic and Anthocyanin Content, Maturity, and Variety of Vaccinium Species. J. Agric. Food Chem. 1998, 46, 2686-2693. [CrossRef]

17. Himed-Idir, H.; Mouhoubi, K.; Siar, E.H.; Boudries, H.; Mansouri, H.; Adjeroud, N.; Boulekbache-Makhlouf, L. Effect of rosemary (Rosmarinus officinalis L.) supplementation on fresh cheese: Physicochemical properties, antioxidant potential, and sensory attributes. J. Food Process. Preserv. 2021, 45, e15057. [CrossRef]

18. Abdelfadel, M.M.; Khalaf, H.H.; Sharoba, A.M.; Assous, M.T.M. Effect of Extraction Methods on Antioxidant and Antimicrobial Activities of Some Spices and Herbs Extracts. J. Food Technol. Nutr. Sci. 2016, 1, 1-14. 
19. Gomaa, M.A.E. Nutraceuticals Impact on Probiotics Growth: A Challenge in Synbiotic-Yoghurt Production. J. Food Dairy Sci. 2018, 9, 41-49. [CrossRef]

20. Almela, L.; Sánchez-Muñoz, B.; Fernández-López, J.A.; Roca, M.J.; Rabe, V. Liquid Chromatograpic-Mass Spectrometric Analysis of Phenolics and Free Radical Scavenging Activity of Rosemary Extract from Different Raw Material. J. Chromatogr. A 2006, 1120, 221-229. [CrossRef]

21. Moo-Huchin, V.M.; Estrada-Mota, I.; Estrada-León, R.; Cuevas-Glory, L.; Ortiz-Vázquez, E.; y Vargas, M.D.L.V.; Betancur-Ancona, D.; Sauri-Duch, E. Determination of Some Physicochemical Characteristics, Bioactive Compounds and Antioxidant Activity of Tropical Fruits from Yucatan, Mexico. Food Chem. 2014, 152, 508-515. [CrossRef]

22. Rodushkin, I.; Ruth, T.; Huhtasaari, A. Comparison of Two Digestion Methods for Elemental Determinations in Plant Material by ICP Techniques. Anal. Chim. Acta 1999, 378, 191-200. [CrossRef]

23. Hwang, H.; Winkler-Moser, J.K.; Liu, S.X. Study on Antioxidant Activity of Amino Acids at Frying Temperatures and Their Interaction with Rosemary Extract, Green Tea Extract, and Ascorbic Acid. J. Food Sci. 2019, 84, 3614-3623. [CrossRef]

24. Pratap-Singh, A.; Fathordoobady, F.; Guo, Y.; Singh, A.; Kitts, D.D. Antioxidants help favorably regulate the kinetics of lipid peroxidation, polyunsaturated fatty acids degradation and acidic cannabinoids decarboxylation in hempseed oil. Sci. Rep. 2020, 10, 10567. [CrossRef] [PubMed]

25. Kolayli, S.; Sahin, H.; Aliyazicioglu, R.; Sesli, E. Phenolic Components and Antioxidant Activity of Three Edible Wild Mushrooms from Trabzon, Turkey. Chem. Nat. Compd. 2012, 48, 137-140. [CrossRef]

26. Ehsani, A.; Banihabib, E.K.; Hashemi, M.; Saravani, M.; Yarahmadi, E. Evaluation of Various Properties of Symbiotic Yoghurt of Buffalo Milk. J. Food Process. Preserv. 2016, 40, 1466-1473. [CrossRef]

27. AOAC. Official Methods of Analysis, 18th ed.; Association of Official Analytical Chemists: Washington, DC, USA, 2007.

28. Richardson, H.G. Standard Methods for the Examination of Dairy Products, 15th ed.; Amr. Public Health Association: Washington, DC, USA, 1986.

29. Harrigan, W.F.; McCance, M.E. Laboratory Methods in Food and Dairy Microbiology; Academic Press Inc. (London) Ltd.: London, $\mathrm{UK}, 1976$.

30. Nelson, J.A.; Trout, G.M. Judging Dairy Products; Wis. 53212; The Olsen Publishing Co: Milwaukee, WI, USA, 1964.

31. Erkan, N.; Ayranci, G.; Ayranci, E. Antioxidant Activities of Rosemary (Rosmarinus officinalis L.) Extract, Blackseed (Nigella Sativa L.) Essential Oil, Carnosic Acid, Rosmarinic Acid and Sesamol. Food Chem. 2008, 110, 76-82. [CrossRef] [PubMed]

32. Khalil, R.K.S.; Gomaa, M.A.E. Prevalence and Characterization of Shiga Toxin-Producing Escherichia Coli (STEC) in Fruits and Vegetables Sold at Local Street Markets in Alexandria, Egypt. LWT 2016, 74, 199-210. [CrossRef]

33. Trojakova, L.; Réblová, Z.; Nguyen, H.T.H.I.T.H.U.; Pokornya, J.A.N. Antioxidant Activity of Rosemary and Sage Extracts in Rapeseed Oil. J. Food Lipids 2001, 8, 1-13. [CrossRef]

34. Lee, C.-Y.; Kim, K.-M.; Son, H.-S. Optimal Extraction Conditions to Produce Rosemary Extracts with Higher Phenolic Content and Antioxidant Activity. Korean J. Food Sci. Technol. 2013, 45, 501-507. [CrossRef]

35. Boix, Y.F.; Dubois, A.E.F.; Hendrix, S.; Luna, L.M.G.; Beenaerts, N.; Manrique, C.E.M.; Victório, C.P.; Cuypers, A. Assessment of the Antioxidative Potential of Rosmarinus officinalis L. (Lamiaceae) Irrigated with Static Magnetic Field-Treated Water. Brazilian Arch. Biol. Technol. 2020, 63. [CrossRef]

36. Daghestani, M.; Al Rashed, S.A.; Bukhari, W.; Al-Ojayan, B.; Ibrahim, E.M.; Al-Qahtani, A.M.; Merghani, N.M.; Ramadan, R.; Bhat, R.S. Bactericidal and Cytotoxic Properties of Green Synthesized Nanosilver Using Rosmarinus officinalis Leaves. Green Process. Synth. 2020, 9, 230-236. [CrossRef]

37. Peixoto, J.A.B.; Álvarez-Rivera, G.; Alves, R.C.; Costa, A.S.G.; Machado, S.; Cifuentes, A.; Ibáñez, E.; Oliveira, M.B.P.P. Comprehensive Phenolic and Free Amino Acid Analysis of Rosemary Infusions: Influence on the Antioxidant Potential. Antioxidants 2021, 10, 500. [CrossRef]

38. Popescu, G.; Iancu, T.; Popescu, C.A.; Stanciu, S.M.; Luca, R.; Imbrea, F.; Radulov, I.; Sala, F.; Moatar, M.M.; Camen, D.D. The Influence of Soil Fertilization on the Quality and Extraction Efficiency of Rosemary Essential Oil (Rosmarinus officinalis L.). Rom. Biotechnol. Lett. 2020, 25, 1961-1968. [CrossRef]

39. Kostikova, V.A.; Veklich, T.N. HPLC Analysis of Phenolic Compounds in Leaves and Inflorescences of Sorbaria Pallasii. In BIO Web of Conferences; EDP Sciences: Les Ulis, France, 2020; Volume 24, p. 40.

40. Nour, V.; Trandafir, I.; Cosmulescu, S. HPLC Determination of Phenolic Acids, Flavonoids and Juglone in Walnut Leaves. J. Chromatogr. Sci. 2013, 51, 883-890. [CrossRef]

41. Gini, T.G.; Jeya Jothi, G. Column Chromatography and HPLC Analysis of Phenolic Compounds in the Fractions of Salvinia Molesta Mitchell. Egypt. J. Basic Appl. Sci. 2018, 5, 197-203. [CrossRef]

42. Joung, J.Y.; Lee, J.Y.; Ha, Y.S.; Shin, Y.K.; Kim, Y.; Kim, S.H.; Oh, N.S. Enhanced Microbial, Functional and Sensory Properties of Herbal Yogurt Fermented with Korean Traditional Plant Extracts. Korean J. food Sci. Anim. Resour. 2016, 36, 90. [CrossRef] [PubMed]

43. Singh, G.; Kapoor, I.P.S.; Singh, P. Effect of Volatile Oil and Oleoresin of Anise on the Shelf Life of Yogurt. J. Food Process. Preserv. 2011, 35, 778-783. [CrossRef]

44. Gorissen, L.; Weckx, S.; Vlaeminck, B.; Raes, K.; De Vuyst, L.; De Smet, S.; Leroy, F. Linoleate Isomerase Activity Occurs in Lactic Acid Bacteria Strains and Is Affected by PH and Temperature. J. Appl. Microbiol. 2011, 111, 593-606. [CrossRef] [PubMed] 
45. Smith-Palmer, A.; Stewart, J.; Fyfe, L. The Potential Application of Plant Essential Oils as Natural Food Preservatives in Soft Cheese. Food Microbiol. 2001, 18, 463-470. [CrossRef]

46. Xu, H.; Lee, H.Y.; Hwang, B.; Nam, J.H.; Kang, H.Y.; Ahn, J. Kinetics of Microbial Hydrogenation of Free Linoleic Acid to Conjugated Linoleic Acids. J. Appl. Microbiol. 2008, 105, 2239-2247. [CrossRef] [PubMed]

47. Kaminarides, S.; Stamou, P.; Massouras, T. Comparison of the Characteristics of Set Type Yoghurt Made from Ovine Milk of Different Fat Content. Int. J. Food Sci. Technol. 2007, 42, 1019-1028. [CrossRef]

48. Hekmat, S.; Soltani, H.; Reid, G. Growth and Survival of Lactobacillus Reuteri RC-14 and Lactobacillus Rhamnosus GR-1 in Yogurt for Use as a Functional Food. Innov. Food Sci. Emerg. Technol. 2009, 10, 293-296. [CrossRef] 